16. Frank Lichtenberg. The Impact of New Drug Launches on Longevity: Evidence from Longitudinal, Disease-Level Data from 52 Countries, 1982-2001. Columbia University. [in Eng.]

\title{
Summary
}

The article highlights topical problems of protection of intellectual property rights in the domestic pharmaceutical industry. The effectiveness of the use of innovative medicines in the field of health is revealed. Having analyzed the norms of international and national legislation, the content of pharmaceutical products as an object of intellectual property rights in Ukraine is revealed and the state of the national legal mechanism of protection of intellectual rights in the field of pharmacy is determined. Using systemic and formal-logical methods, the procedure of compulsory licensing of patented inventions (utility models) is characterized and the main problems of its realization are formed. It has been identified that the main problems in the protection of intellectual property rights in the pharmaceutical sector include: public awareness of the effectiveness of health care innovations for the state and the patient; limited access of Ukrainian patients to innovative pharmaceutical products. inefficiency of the state policy on the development of innovative medicines; the lack of a transparent and understandable mechanism for the compulsory licensing of patented inventions to all interested parties.

In order to overcome these problems, it is proposed to harmonize the national system of protection and protection of intellectual property rights in accordance with the Association Agreement between Ukraine and the EU.

Keywords: medicines, intellectual property rights, protection of rights, pharmaceutical industry.

UDC 341.96

DOI 10.31733/2078-3566-2019-5-157-163

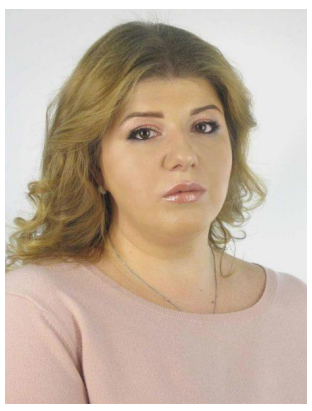

Krystyna REZVOROVYCH ${ }^{\odot}$

$\mathrm{Ph} . \mathrm{D}$

(Dnipropetrovsk State University

of Internal Affairs)

\section{LEGAL STATUS OF TRANSNATIONAL CORPORATIONS IN PRIVATE INTERNATIONAL LAW}

КОРстина Резворович. ПРАВОВИЙ СТАТУС ТРАНСНАЦІОНАЛЬНИХ КОРПОРАЦІЙ В МІЖНАРОДНОМУ ПРИВАТНОМУ ПРАВІ. КЛЮчОВою тендеНцією сучасних міжнародних відносин $є$ глобалізація світового господарства, лібералізація торгівлі $\mathrm{i}$, як наслідок, інтернаціоналізація капіталу та розвиток міжнародного підприємництва, чому активно сприяє науково-технічний прогрес і новітні технології.

Стаття присвячена проблематиці правового статусу транснаціональних корпорацій у міжнародному приватному праві. Зокрема, 3 урахуванням сучасної доктрини, національного законодавства і міжнародних документів. В статті досліджується поняття транснаціональної корпорації 3 урахуванням iї якісних і кількісних характеристик. Аналізуються положення документів ООН Проект Кодексу поведінки транснаціональних корпорацій 1983 року і Проект норм, що стосуються обов'язків транснаціональних корпорацій та інших підприємств в області прав людини 2003 р.; СНД Конвенція про транснаціональні корпорації 1998 року, а також акти Європейського Союзу.

Розкрито особливості правового регулювання статусу транснаціональних корпорацій, зокрема права, обов'язки, відповідальність, порядку створення і припинення діяльності. Специфіка правового статусу ТНК зумовлена тим, що правове регулювання їхньої діяльності здійснюється на основі норм національного законодавства кількох держав (держави реєстрації, держави розташування), двосторонніх угод, багатосторонніх договорів та міжнародних рекомендаційних актів. На сьогодні, на міжнародному рівні не вдалося прийняти юридично обов'язковий акт, в якому наводяться вичерпні ознаки ТНК, їхні права та обов'язки. У зв'язку з цим, кваліфікація утворення як ТНК залишається складним теоретичним і практичним завданням. Відсутність такого акта пояснюється неспроможністю держав віднайти компромісний підхід щодо ключових положень, що стосуються їхнього правового статусу. Це слід розглядати як негативне явище, оскільки підходи держав щодо статусу ТНК можуть бути суттєво відмінними і створювати бар'єри для руху іноземного інвестування

В умовах відсутності єдності регулювання статусу транснаціональних корпорацій в законодавстві держави наголошується на необхідності прийняття універсального міжнародного договору.

Ключові слова: транснаціональна корпорація, ТНК, транснаціональна група, багатонаціональна корпоращія, мультинаціональна корпорачія, права і обов'язки транснаціональних корпорачій, статус трансначіональних корпорачій, міжнародне приватне право.

(C) Rezvorovych K., 2019

ORCID iD: https://orcid.org/0000-0003-1183-613X

goldkristina@gmail.com 
Problem statement. The key trend of modern international relations is the globalization of the world economy, trade liberalization and, as a consequence, internationalization of capital and the development of international entrepreneurship, which is actively contributed by scientific and technological progress and the latest technologies. Under these conditions, the role and value of transnational corporations (hereinafter referred to as the "TNCs") is increasing, and their number is growing. According to the Organization for Economic Co-operation and Development, there were about 38,000 TNCs with more than 206,000 branches worldwide in 2000, while there were about 60,000 TNCs with more than 500,000 foreign affiliates in 2006 [1].

According to the researchers, the functioning of TNCs is the basis of economic growth and technological progress both globally and nationally. Taxes paid by TNCs are a significant source of replenishment of the state budget. They also create jobs and thereby stabilize national labour markets. For example, in 2015, General Motors employed about 708,000 people; Siemens - 486,000; Ford Motor - 464,000 [2, p. 152], etc.

Over the last decades, TNCs have controlled "over $50 \%$ of international trade in manufactured goods, about $80 \%$ of patents and licenses for new machinery and technologies. TNCs control $90 \%$ of the world market for wheat, corn, coffee, tobacco, $75 \%$ of crude oil and natural rubber" [3, p. 106-107]. The largest corporations have turned into powerful profit entities with their annual budget exceeding that of many countries. Under these conditions, the activities of corporations can be a challenge for the functioning of states, since, because of their economic power, TNCs have the real capacity and resources to significantly influence national domestic and foreign policy, the economy and even the development of legislation.

Thus, transnational corporations are one of the most important actors in the modern international relations, and the problem of legal regulation of their status is one of the most relevant in private international law.

Analysis of publications that started solving this problem. It should be noted that the issue of TNCs functioning in the doctrine has traditionally been of considerable academic interest. In particular, the following Ukrainian scholars are worth noting: Ye.M. Bilousova, I.I. Dakhno, A.S. Dovhert, I.M. Zhukov, Yu.F. Ivanov, V.V. Komarov, T.V. Kurman, O.O. Merezhko, O.P. Radchuk, and I.A. Shumilo. Among the Russian scholars, the following are worth noting: M.M. Boguslavsky, E.A. Gorlov, A.E. Korolev, R.A. Kulikov, D.L. Lysenko, L.A. Lunts, A.A. Mironov, S.Yu. Pechekina. In American and European science, the topic of TNC legal capacity has also been the subject of research by many scholars, including D. Ashtrom, P. Gray, J.H. Dunning, R. Jenkis, A. de Lond, B. McKern, and E. Ochionebo, K. Sauwant, D. Chudnovsky, O. de Schutter. However, given the complexity and diversification of international relations, the emergence of new legal instruments and mechanisms, the study of the status of TNCs remains an important scientific task.

The article's objective is to determine the features of TNCs' status in private international law at the present stage.

Basic content. Research into the legal status of TNCs in private international law should begin with the concept of a transnational corporation.

First of all, we should pay attention to the terminology used to refer to TNCs. Most post-Soviet researchers use the term "transnational corporation". It is this term ("transnational corporation") that has been widely used in the UN documents (such as the 1983 Code of Conduct for Transnational Corporations [4]), its bodies, in particular the United Nations Conference on Trade and Development (UNCTAD) (International Investment Report 2019 [5]) and specialized agencies - the United Nations Industrial Development Conference (UNIDO) (Transnational Corporations and the Internationalization of R\&D: 2005 World Investment Report [6]) and the EU (Directive 2014/66/EU on the conditions of entry and residence of thirdcountry nationals in the framework of an intra-corporate transfer [7]). At the same time, doctrines and international practices also include synonymous equivalents, namely multinational (international) corporations (companies, enterprises). In particular, such terminology is used by the Organization for Economic Co-operation and Development (OECD) in the 1976 Declaration on International Investment and Multinational Enterprises and Guidelines for Multinational Enterprises, as amended in 2011 [8]. The lack of terminological unity in the doctrine can also be explained by the different variants of translation from the authentic language of the document, as well as the use of different terminology in national law.

It should be noted that the term "multinational corporation" is not used in Ukrainian law. Art. 119(2) of the Economic Code of Ukraine, 2003 [9] (hereinafter referred to as the "EC of Ukraine") contains a more general concept - "economic association", which means "associ- 
ation of enterprises formed at the initiative of enterprises, regardless of their type, which voluntarily combined their economic activities." According to Art. 120(1) of the EC of Ukraine, economic associations may be formed as associations, corporations, consortia, concerns or other associations of enterprises provided by law. According Art. 120(3) of the EC of Ukraine, the corporation shall be "a contractual association established on the basis of a combination of production, scientific and commercial interests of the merged companies, with the delegation of separate powers of centralized regulation of the activity of each of the participants to the governing bodies of the corporation." Therefore, the corporation is regarded by the legislator as one of the legal forms of business associations.

Noteworthy is the position of the Russian scholar D.L. Lysenko, who, in his thesis "The Problem of the Legal Status of Transnational Corporations: International Legal Aspects" (Moscow, 2003), indicates that the term "transnational corporation" is unsuccessful, as in most cases it brings together quite different corporations or other legal entities, as well as organizations that do not have the status of the legal entity. In this regard, he proposes to use the term "transnational group", which may be appropriate in the context of the different nature of such entities [10, p. 16].

The study of specialized literature on private international law leads to the conclusion that today there is no complete accord among scholars regarding the definition of TNCs and their characteristic features. According to J.H. Dunning, TNCs are "a structure that owns and controls production assets in two or more foreign countries" [11, p. 23]. Shkurat I. considers transnational corporation to be a group of enterprises operating in different countries (host countries) but controlled by a headquarters located in one particular country, with the main feature of TNCs being foreign direct investment from the host country [12, p. 436]. Dakhno I.I. argues that TNCs are an economically unified system formed by a group of independent, mutually segregated enterprises, which have structural subdivisions and operate in the territories of several states, with their activity regulated by the national legislation of these states [13, p. 81]. A rather abstract definition is offered by V.I. Smagin, who points out that TNCs are a "complex that uses an international approach in its activities, which involves the formation of a transnational industrial, financial, and trade complex with a single decision-making center" [14, p. 66].

There were also attempts to define the concept of TNCs in international instruments. In particular, in paragraph 1(a) of the 1983 Draft United Nations Code of Conduct for Transnational Corporations [4], the term "transnational corporation" is defined as an enterprise consisting of subdivisions in two or more countries that have coherent policies and a common strategy, and are interconnected by a joint decision-making systems from one or more centers that have a significant impact on the activities of other components, in particular, sharing of knowledge, resources and responsibility. At the same time, the draft states that its provisions apply to enterprises regardless of their country of origin and ownership - private, public (state) or mixed. Paragraph 20 of the 2003 Draft Norms on the Responsibilities of Transnational Corporations and Other Business Enterprises with Regard to Human Rights [15] provides a close definition with the only clarification that TNCs can act in any legal form, and act individually or collectively.

A broader definition of TNCs is provided in the 2005 Report of the United Nations Industrial Development Organization (UNIDO) Conference on Global Investments, Transnational Corporations and Internationalization of R\&D. In particular, transnational corporations are regarded as incorporated or unincorporated enterprises, including a parent company and its foreign affiliates. A parent company is defined as an enterprise that controls the assets of other entities in countries other than its home country, typically owning a certain share of its equity. A share of equity is $10 \%$ or more of ordinary shares or voting rights for registered enterprises, or its equivalent for an unincorporated enterprise, is generally considered as an asset control threshold. A foreign affiliate is an incorporated or unincorporated enterprise in which an investor resident in another country owns a share that allows for long-term management of the enterprise (the shareholding is up to $10 \%$ for the incorporated enterprise or its equivalent for an unincorporated enterprise). The affiliate is wholly or jointly owned by the unincorporated enterprise in the host country, which may include (i) a permanent representative office or office of a foreign investor; (ii) an unincorporated partnership or joint venture between a direct foreign investor and one or more third parties; (iii) land plots, structures (except for governmentowned structures) and/or real property and facilities directly owned by a foreign resident; or (iv) movable property (such as ships, aircrafts, gas drilling rigs) operating in a country other than a foreign investor's country for at least one year [16, p. 297].

In our opinion, the definition of TNCs should be given by systematically interpreting its 
essential features. The approach that distinguishes qualitative and quantitative criteria (B.M. Ashavsky, N. Valko, D.L. Lysenko, L.I. Lialikova), which reveal the nature of TNCs and allow distinguishing them from other entities, is quite widely used in the science. Qualitative criteria reflect the nature of TNCs, and quantitative criteria reflect their variable characteristics.

Qualitative characteristics include the form of ownership, the procedure for creation and registration, the structure of the corporation, the distribution of assets and liabilities, management and control. Baad H. defines TNC as an enterprise with headquarters located in the country of origin, which controls the activities of subsidiaries in the countries of location. Vernon R. adds that all the enterprises (companies) of the group united in TNCs have a single source of finance and personnel. The organizational structure of TNCs can be both centralized and decentralized. However, in any structure all elements of this structure are interconnected. Despite economic unity, TNCs are characterized by the independence of legal entities that are part thereof, which may have different state affiliations [17, p. 12].

Quantitative characteristics include the ratio of foreign assets to the total assets of the corporation; the ratio of the number of foreign workers to the general staff of the corporation; the ratio of the share of profit earned abroad to the total profit; the ratio of imports to total sales. At the same time, scholars provide significantly different indicators of the quantitative characteristics of TNCs or do not provide sufficient arguments for specific numerical indicators. Thus, scholars distinguish at least two (J.H. Dunning, I.I. Dakhno, I.M. Zhukov) to six countries (R. Vernon), where TNCs should operate or have affiliates. According to V. Rugman, the ratio of imports to total sales should be at least 30\%. Vernon R. states that TNCs' overseas sales should be at least $\$ 100$ million per year [See: 18, p. 21].

The specifics of TNCs status is due to the fact that the legal regulation of their activities is carried out on the basis of the provisions of national legislation, bilateral agreements, multilateral treaties and international advisory acts.

The provisions of national law apply to the activities of enterprises and their affiliates forming a group of TNCs located in the territory of the respective state. However, the peculiarities of legal regulation of TNCs is that a corporation, having offices in several countries, does not fall under the jurisdiction of an individual state, and its activities as a single entity cannot be regulated by the national law of one state. The extraterritorial effect of national legislation is possible only with the consent of other countries, which is enshrined in the relevant international treaties.

In some countries, attempts have been made to unilaterally extend the provisions of their legislation to regulate the activities of TNC subdivisions in the territory of other countries. An example would be the US practice reflected in the 1979 Export Administration Act [19]. In this connection, a number of the UN recommendations stated the principle that the rules of the country of location apply to foreign affiliates and enterprises of TNCs.

The next level of regulation is bilateral agreements concluded between countries on foreign investment and related legal relations. According to the official information of the Ministry of Foreign Affairs of Ukraine, today Ukraine is a party to about 70 such agreements [20]. The provisions of such agreements provide for investment protection and impose obligations on countries to create favourable, transparent and non-discriminatory conditions for investors from another country. Thus, in the territory of Ukraine the national regime of investment activity is applied to foreign investors, i.e. equal conditions of activity with domestic investors are provided. Foreign investments in Ukraine are not subject to nationalization. In case of termination of the investment activity, the foreign investor is guaranteed the return of his/its investment in kind or in the currency of investment without payment of duties, as well as income from investments in cash or commodity form. The State also guarantees the unimpeded and immediate transfer abroad of foreign currency profits and other funds legally obtained as a result of foreign investments.

The third level of regulation of TNCs is international multilateral acts, which are mainly advisory in nature.

It should be noted that attempts have been made within the UN and its specialized agencies to adopt a universal international treaty on the status of TNCs. A significant contribution was made by the United Nations Conference on Trade and Development (UNCTAD) and the Center for Transnational Corporations, which since 1993 has been replaced by the Investment, Enterprise and Development Commission. In 1975, they introduced the United Nations Code of Conduct for Transnational Corporations [4], which was repeatedly submitted by the UN General Assembly for consideration by Member States in order to make it a legally binding act in the form of an international treaty. The Code provides for mutual commitments between the 
States and TNCs. In particular, the key principle determined therein is the principle of nondiscrimination against a foreign partner. Therefore, the state must create equal conditions for the functioning of national and foreign entities. In doing so, TNCs should promote the development of the country's scientific and technical potential, comply with the requirements of national legislation of the country, and report on their activities. It should be noted that as of July 14, 2019, the said act has not yet become legally binding.

Among the documents developed within the UN framework, the 2003 Draft Norms on the Responsibilities of Transnational Corporations and Other Business Enterprises with Regard to Human Rights [15] (hereinafter referred to as "the Draft Norms") should also be noted. The preamble to this act recognizes that TNCs, their employees, have their own responsibilities and bear responsibility in the field of human rights, which are not absorbed by the obligations of the State of incorporation or other States where they operate. The Draft Norms contain provisions that impose the same obligations on TNCs as on the states. In particular, to guarantee the right to equal opportunities and to ensure non-discriminatory treatment (paragraph B); to abide by the rules of public international law in the field of human rights and, in particular, not to be involved in the commission of international crimes (paragraph C), not to use forced labor (paragraph D); respect the provisions of national law and the sovereignty of the state (paragraph E); comply with the rules of fair business practice, marketing, advertising, ensure the proper quality of goods and services (paragraph F); in the pursuit of its activities, to anticipate the requirements of the environment, health, bioethics (paragraph $\mathrm{G}$ ).

The regulation of TNCs through legally binding acts is now carried out at the regional level. Thus, the CIS 1998 Convention on Transnational Corporations [21], which came into force on 14.01.2000, is of great importance. Unlike the above-mentioned UN acts, it regulates the status of TNCs in more detail. Thus, the Convention defines a transnational corporation, contains rules on its composition, procedure for establishment, registration and termination, governing bodies, state support and promotion of activities, responsibility of participants, reporting and control over its activities, ownership of profits and products.

In particular, it is recognized that the members of the corporation may be legal entities in any legal form, as well as state, municipal and unitary enterprises (Article 3). The procedure for registering TNCs is determined by the law of the state - the place of its registration. The registration is confirmed by the issuance of a certificate of the established form, stating the full name and legal form with the obligatory indication that it is a transnational corporation (Article 4). The governance structure, in particular the composition of the supreme, executive and controlling bodies, is determined by the statutory documents of the corporation, based on the legislation of the state of registration (Article 6). According to the obligations of the corporation, participants are responsible under the laws of those states whose legal entities are members of the corporation (Article 9). The corporation is required to report on its activities in the manner specified by the law of the country of incorporation. At the same time, legal entities that are members of the corporation report by location. The competent authority of the State of incorporation may audit activities of the corporation (Article 10). As a general rule, the right of ownership of the corporation and its legal entities of profit and production is determined by the law of the country of location, unless otherwise specified by interstate agreements. Taxation of legal entities belonging to the corporation is carried out at the place of their location according to the legislation of the country of residence (Article 11). Regulation of labour and social relations in a corporation is carried out under the laws of the states in whose territory its members are located, unless otherwise specified by the respective states (Article 12). The corporation may be liquidated on the grounds stipulated by the law of the country of incorporation, as well as under interstate agreements.

TNCs are also regulated within the framework of the European Union. However, to date, it mainly concerns reporting on TNCs' activities in terms of functioning of the EU internal market. In particular, Council Directive 2011/16/EU on mandatory automatic exchange of tax information concerning cross-border arrangements has been in force since 15.02.2011 [22]. At the same time, the Council of the European Union and the European Parliament have failed to adopt a Code of Conduct for European TNCs due to resistance from Member States (see European Code of Conduct: Resolution on EU Standards for European Enterprises Operating in Developing Countries [23]).

Conclusions. Specifics of the legal status of TNCs is due to the fact that the legal regulation of their activities is carried out on the basis of the rules of national legislation of several states (state of incorporation, country of location), bilateral agreements, multilateral agreements and international advisory instruments. They have failed to adopt a legally binding act outlining 
TNCs, their rights and obligations so far at the international level. In this regard, qualification of such entities as TNCs remains a difficult theoretical and practical task. The absence of such an act is explained by the inability of states to find a compromise approach on key provisions regarding their legal status. This should be seen as a negative phenomenon, as states' approaches to the status of TNCs can be significantly different and create barriers to foreign investment.

\section{References:}

1. AMNE Database - Activity of Multinational Enterprises. Organization for Economic Cooperation and Development. URL: https://www.oecd.org/sti/ind/amne.htm.

2. Kordos M., Vojtovic S. Transnational corporations in the global world economical environment. Procedia. Social and Behavioral Sciences, 230, 150-158 (2016).

3. Жушман В. П., Шуміло І. А. Міжнародне приватне право: підруч. для студ. юрид. вищ. навч. закл. Харків : Право, 2012. 320 с.

4. Draft United Nations Code of Conduct on Transnational Corporations 1983. URL: https://www.cambridge.org/core/journals/international-legal-materials/article/draft-united-nations-codeof-conduct-on-transnational-corporations/77FAB2464C062A749DED60D7CE847497.
5. World Investment
Report
2019.
UNCTAD.
URL:

https://unctad.org/en/PublicationsLibrary/wir2019_en.pdf.

6. Доклад о мировых инвестициях 2005 г.: Транснациональные корпорации и интернационализация НИОКР. URL: https://unctad.org/ru/docs/wir2005overview_ru.pdf).

7. Directive 2014/66/EU of the European Parliament and of the Council of 15 May 2014 on the conditions of entry and residence of third-country nationals in the framework of an intra-corporate transfer. URL: https://eur-lex.europa.eu/legal-content/EN/ALL/?uri=celex\%3A32014L0066).

8. OECD Guidelines for Multinational Enterprises. 2011 Edition. URL: http://www.oecd.org/daf/inv/mne/48004323.pdf.

9. Господарський кодекс України від 16.03.2003 р. Офіційний вісник України № 11, 2003, ст. 462.

10. Лысенко Д. Л.. Проблема правового статуса транснациональных корпораций: международно-правовые аспекты : дисс. ... канд. юрид. наук. М., 2003. 191 с.

11. Dunning J. H. The nature of transnational corporations and their activities. The theory of transnational corporations. United Nation Library of Transnational Corporations, 1, 20-34 (1993).

12. Шкурат I. Транснаціональні корпорації - рушійні сили глобалізації. Вісник Національної академії державного управління при Президентові України. № 2, 2005, С. 55-61.

13. Дахно І. І. Міжнародне економічне право: курс лекцій, 2-е вид. Київ: МАУП, 2003. 408 с.

14. Смагина В. И. Понятие и сущность. Вестник ТГУ. Вып. 8(52), 2007. С. 66-71.

15. Проект норм, касающихся обязанностей транснациональных корпораций и других предприятий в области прав человека от 26.08.2003 г. Экономический и социальный совет ООН. URL: https://undocs.org/pdf?symbol=ru/E/CN.4/Sub.2/2003/12.

16. Transnational Corporations and the Internationalization of R\&D: World Investment Report 2005. URL: https://unctad.org/en/Docs/wir2005_en.pdf

17. Baade H. W. The legal effects of codes of conduct for multinational enterprises. German Yearbook of International Law, 22, 10-22 (1980).

18. Королев А. Е. Транснациональные корпорации как субъекты международного частного права. М., 2003. 135 с.

19. Export Administration Act 1979. URL: https://www.govinfo.gov/content/pkg/STATUTE93/pdf/STATUTE-93-Pg503.pdf).

20. Інвестиційний клімат в Україні. Міністерство закордонних справ України. Офіційний сайт. https://mfa.gov.ua/ua/page/open/id/821.

21. Конвенция о транснациональных корпорациях от 06.03 .1998 г. URL: https://zakon.rada.gov.ua/laws/show/997 193).

22. Council Directive 2011/16/EU of 15 February 2011 on administrative cooperation in the field of taxation and repealing Directive 77/799/EEC. URL: https://eur-lex.europa.eu/legalcontent/EN/TXT/?uri=CELEX:02011L0016-20180101.

23. Towards a European Code of Conduct: Resolution on EU standards for European Enterprises operat$\begin{array}{lcccc}\text { ing } & \text { in } & \text { developing } & \text { countries } & 1998 .\end{array}$ URL:

Received to editorial office 02.12.2019

1. AMNE Database - Activity of Multinational Enterprises. Organization for Economic Cooperation and Development. URL: https://www.oecd.org/sti/ind/amne.htm. [in Eng.]

2. Kordos M., Vojtovic S. Transnational corporations in the global world economical environment. Procedia. Social and Behavioral Sciences, 230, 150-158 (2016). [in Eng.]

3. Zhushman, V. P., Shumilo, I. A. (2012) Mizhnarodne pryvatne pravo [International Private Law]: pidruch. dlya stud. yuryd. vyshch. navch. zakl. Kharkiv : Pravo, 320 s. [in Ukr.]

4. Draft United Nations Code of Conduct on Transnational Corporations 1983. URL: https://www.cambridge.org/core/journals/international-legal-materials/article/draft-united-nations-codeof-conduct-on-transnational-corporations/77FAB2464C062A749DED60D7CE847497. [in Eng.]
5. World
Investment
Report
2019.
UNCTAD.
URL: 
https://unctad.org/en/PublicationsLibrary/wir2019_en.pdf. [in Eng.]

6. Doklad o mirovykh investitsiyakh 2005 g.: Transnatsional'nyye korporatsii i internatsionalizatsiya NIOKR [World Investment Report 2005: Transnational Corporations and the Internationalization of R\&D]. URL: https://unctad.org/ru/docs/wir2005overview_ru.pdf). [in Russ.]

7. Directive 2014/66/EU of the European Parliament and of the Council of 15 May 2014 on the conditions of entry and residence of third-country nationals in the framework of an intra-corporate transfer. URL: https://eur-lex.europa.eu/legal-content/EN/ALL/?uri=celex\%3A32014L0066). [in Eng.]

8. OECD Guidelines for Multinational Enterprises. 2011 Edition. URL: http://www.oecd.org/daf/inv/mne/48004323.pdf. [in Eng.]

9. Hospodars'kyy kodeks Ukrayiny [Economic Code of Ukraine] vid 16.03.2003 r. Ofitsiynyy visnyk Ukrayiny № 11, 2003, st. 462. [in Ukr.]

10. Lysenko, D. L. (2003) Problema pravovogo statusa transnatsional'nykh korporatsiy: mezhdunarodno-pravovyye aspekty [The problem of the legal status of transnational corporations: international legal aspects] : diss. ... kand. yurid. nauk. M., 191 s. [in Russ.]

11. Dunning J. H. The nature of transnational corporations and their activities. The theory of transnational corporations. United Nation Library of Transnational Corporations, 1, 20-34 (1993). [in Eng.]

12. Shkurat, I. (2005) Transnatsional'ni korporatsiyi - rushiyni syly hlobalizatsiyi. Visnyk Natsional'noyi akademiyi derzhavnoho upravlinnya pry Prezydentovi Ukrayiny, № 2, S. 55-61. [in Ukr.]

13. Dakhno I. I. Mizhnarodne ekonomichne pravo [International Economic Law]: kurs lektsiy, 2e vyd. Kyiv: MAUP, 2003. 408 s. [in Ukr.]

14. Smagina V. I. Ponyatiye i sushchnost' [The concept and essence]. Vestnik TGU. Vyp. 8(52), 2007. S. 66-71. [in Russ.]

15. Proyekt norm, kasayushchikhsya obyazannostey transnatsional'nykh korporatsiy i drugikh predpriyatiy v oblasti prav cheloveka [Draft standards on the responsibilities of transnational corporations and other enterprises in the field of human rights] ot $26.08 .2003 \mathrm{~g}$. Ekonomicheskiy i sotsial'nyy sovet OON. URL: https://undocs.org/pdf?symbol=ru/E/CN.4/Sub.2/2003/12. [in Russ.]

16. Transnational Corporations and the Internationalization of R\&D: World Investment Report 2005. URL: https://unctad.org/en/Docs/wir2005 en.pdf. [in Eng.]

17. Baade H. W. The legal effects of codes of conduct for multinational enterprises. German Yearbook of International Law, 22, 10-22 (1980). [in Eng.]

18. Korolev, A. Ye. (2003) Transnatsional'nyye korporatsii kak sub"yekty mezhdunarodnogo chastnogo prava [Transnational corporations as actors of private international law]. M., $135 \mathrm{~s}$. [in Russ.]

19. Export Administration Act 1979. URL: https://www.govinfo.gov/content/pkg/STATUTE93/pdf/STATUTE-93-Pg503.pdf). [in Eng.]

20. Investytsiynyy klimat v Ukrayini [Investment climate in Ukraine]. Ministerstvo zakordonnykh sprav Ukrayiny. Ofitsiynyy sayt. URL : https://mfa.gov.ua/ua/page/open/id/821. [in Ukr.]

21. Konventsiya o transnatsional'nykh korporatsiyakh [Convention on Transnational Corporations] ot 06.03.1998 g. URL: https://zakon.rada.gov.ua/laws/show/997 193). [in Russ.]

22. Council Directive 2011/16/EU of 15 February 2011 on administrative cooperation in the field of taxation and repealing Directive 77/799/EEC. URL: https://eur-lex.europa.eu/legalcontent/EN/TXT/?uri=CELEX:02011L0016-20180101. [in Eng.]

23. Towards a European Code of Conduct: Resolution on EU standards for European Enterprises $\begin{array}{llll}\text { operating in developing } & \text { countries } & 1998 . & \text { URL: }\end{array}$ http://www.europarl.europa.eu/sides/getDoc.do?type=REPORT\&reference=A4-1998-

0508\&language $=$ EN. [in Eng.]

\section{Summary}

The research paper deals with the problems of the legal status of transnational corporations in private international law. In particular, taking into account modern doctrine, national legislation and international documents, the research paper explores the concept of a transnational corporation with regard to its qualitative and quantitative characteristics. The provisions of the UN documents are analyzed - the Draft Code of Conduct for Transnational Corporations, 1983, and Draft Standards on the Responsibilities of Transnational Corporations and Other Business Enterprises with Regard to Human Rights, 2003; CIS - 1998 Convention on Transnational Corporations, and the European Union Acts. The features of legal regulation of the status of transnational corporations, in particular the rights, obligations, responsibilities, procedures for establishment and termination are covered. In the absence of unity of regulation of the status of transnational corporations, state legislation emphasizes the need for adopting a universal international treaty.

Keywords: transnational corporation, TNC, transnational group, multinational corporation, rights and obligations of transnational corporations, status of transnational corporations, private international law. 